\title{
Effect of Oils Sources on Blood Lipid Parameters of Commercial Laying Hens
}

Author(s)

Murata $\mathrm{LS}^{*}$

Ariki $J^{2}$

Machado $C R^{3}$

Silva $L$ da PG da ${ }^{4}$

Rezende MJM

Docente da Faculdade de Agronomia e Medicina Veterinária da UnB - Brasília/DF.

2 Docente do Departamento de Zootecnia de Não Ruminantes da FCAV/UNESP - Jaboticabal/ $\mathrm{SP}$.

${ }^{3}$ Docente do Departamento de Morfologia e Fisiologia Animal da FCAV/UNESP.

${ }^{4}$ Docente do Departamento de Zootecnia da UFPB - Areia/PB.

\section{Mail Address}

Luci Sayori Murata

Universidade de Brasília (UnB)

Faculdade de Agronomia e Medicina Veterinária (FAV)

Campus Universitário Darcy Ribeiro

Caixa Postal 4508

Asa Norte - Brasília, DF

70.910-900

E-mail:mluci@unb.br

\section{Keywords}

Blood lipids, diet, laying hens, oil source.

\section{Acknowledgments}

We wish to thank COCAMAR, Granja Mizumoto, and Granja Sertanejo for providing the oils used in this research.

\section{ABSTRACT}

The experiment was carried out to verify if total cholesterol, HDLcholesterol and triacylglicerol plasma levels are affected when laying hens are fed rations containing different dietary oil sources. One hundred sixty 50 week-old hens, assigned to four treatments with five replicates using 8 hens per replicate were used. The experimental period was of 84 days divided in 3 cycles of 28 days each. In the last day of each cycle, blood samples of 2 hens per replicate were randomly choose and blood samples were collected. On the other hand, blood was also collected at 7 am, 11 am and $3 \mathrm{pm}$ aiming to study the daily changes of these lipids. Blood lipid parameters were not affected by different dietary oil sources $(p>$ 0.05); however, HDL-cholesterol did change during the day, giving evidence that this lipid is indeed involved in the egg yolk formation.

\section{INTRODUCTION}

The search of new procedures to improve the quality of foods of animal origin is an unquestionable tendency in animal production. One of the relevant subjects, in this context, is the attempt to improve the quality of the egg yolk lipids content profile of commercial laying hens for human consumption.

Egg is constituted mainly by water, which correspond, approximately, to $75 \%$ of the total egg weight. However, chemical components of the egg are not uniformly distributed between the yolk and albumen, with the albumen volume being twice of the yolk. Although both fractions contain similar amount of proteins, carbohydrates, and minerals, the yolk contains all lipids of the egg (Romanoff \& Romanoff, 1963).

Nutrition, genetic and pharmacological agents can affect cholesterol deposition in the egg yolk (Hargis, 1988). Concerning nutrition, one of the methods developed to change the lipid profile of eggs has been the use of oil types rich in fatty acids (Leaf \& Weber, 1988), commonly used as a source of energy in the diets of laying hens.

Connor et al. (1965) demonstrated that laying hens transfer blood cholesterol for yolk development and has been constituted in the principal mechanism of cholesterol excretion (Naber, 1976), followed by bile excretion (Hargis, 1988).

The organ where most of the lipogenesis takes place in poultry is the liver. Considering the ingredients of a ration, especially vegetables, cholesterol free, all lipid fractions deposited in the yolk are synthesized in the liver, which are afterwards sent through blood stream to different tissues of the body.

The results in the literature regarding the effect of dietary fatty acids intake on egg and plasma cholesterol concentrations are contradictory. Hollands et al., (1980) and Mori et al., (1999) verified that polyunsaturated fatty acids of dietetic oils decrease both the egg and the plasma cholesterol 
concentrations. On the other hand, Bartov et al. (1971) and Washburn \& Nix (1974) did not observe such effect.

Oils have commonly been used as energy sources in diets for laying hens. Some of these oil sources are rich in elements such as long chain polyunsaturated fatty acid that can change the proportion of the constituents of the egg yolk.

The aim of this experiment was to verify the plasma levels of total cholesterol (mg/dL), HDL-cholesterol (mg/ $\mathrm{dL})$, and triacylglicerol $(\mathrm{mg} / \mathrm{dL})$ in laying hens blood, fed diets containing different oil sources.

\section{MATERIAL AND METHODS}

Fifty week-old Lohmann White laying hens were used. These hens were fed diets containing soy, fish, canola and poultry by-product oils at the $3 \%$ level and soy oil was used as the control, following the recommendations of NRC (1994) (Table 1). Experimental diets and water were provided for ad libitum consumption. Table 2 shows the fatty acids composition of each oil source.

Table 1 - Composition of experimental diets for laying hens.

\begin{tabular}{|c|c|c|c|c|}
\hline \multirow[t]{2}{*}{ Ingredients (\%) } & \multicolumn{4}{|c|}{ Oil source } \\
\hline & Soy & Fish & Canola & $\begin{array}{r}\text { Poultry by } \\
\text { product }\end{array}$ \\
\hline Corn & 58.50 & 58.40 & 57.60 & 58.10 \\
\hline Soybean meal & 26.30 & 26.30 & 26.40 & 26.50 \\
\hline Oil & 3.00 & 3.00 & 3.00 & 3.00 \\
\hline Limestone & 8.70 & 8.70 & 8.70 & 8.70 \\
\hline Salt & 0.30 & 0.30 & 0.30 & 0.30 \\
\hline Mineral mixture ${ }^{1}$ & 0.30 & 0.30 & 0.30 & 0.30 \\
\hline Vitamin mixture $^{2}$ & 0.25 & 0.25 & 0.25 & 0.25 \\
\hline Dicalcium phosphate & 1.80 & 1.80 & 1.80 & 1.80 \\
\hline DL-methionine & 0.04 & 0.04 & 0.04 & 0.04 \\
\hline \multirow[t]{2}{*}{ Inert $^{3}$} & 0.81 & 0.91 & 1.51 & 1.11 \\
\hline & 100.00 & 100.00 & 100.00 & 100.00 \\
\hline \multicolumn{5}{|c|}{ Calculated nutrient content } \\
\hline Crude protein, \% & 17 & 17 & 17 & 17 \\
\hline Metabolizable energy, kcal/kg & 2850 & 2850 & 2850 & 2850 \\
\hline Calcium, \% & 3.70 & 3.70 & 3.70 & 3.70 \\
\hline Available phosphorus, \% & 0.40 & 0.40 & 0.40 & 0.40 \\
\hline Methionine, \% & 0.30 & 0.30 & 0.30 & 0.30 \\
\hline Methionine+Cystine, \% & 0.55 & 0.55 & 0.55 & 0.55 \\
\hline \multicolumn{5}{|c|}{$\begin{array}{l}1 \text { - Supplied per kilogram of diet: } 15.000 \mathrm{mg} \text { (Iron), } 12000 \mathrm{mg} \text { (Cooper), } \\
35.000 \mathrm{mg} \text { (Manganese), } 30.000 \mathrm{mg} \text { (Zinc), } 600 \mathrm{mg} \text { (lodine), } 70 \mathrm{mg} \\
\text { (Selenium). } 2 \text { - Supplied per kilogram of diet: } 3.500 .000 \mathrm{UI} \text { (vitamin A), } \\
\left.700.000 \mathrm{UI} \text { (vit } \mathrm{D}_{3} \text { ), } 2.500 \mathrm{mg} \text { (vitamin E), } 670 \mathrm{mg} \text { (vitamin } \mathrm{K}_{3}\right), 6.000 \mathrm{mcg} \\
\text { (vitamin } \mathrm{B}_{12} \text { ), } 1.500 \mathrm{mg}\left(\mathrm{B}_{2} \text { ), } 2.500 \mathrm{mg} \text { (pantothenic acid), } 6.000 \mathrm{mg}\right. \\
\text { (nicotinic acid), } 80 \mathrm{~g} \text { (choline chloride), } 120 \mathrm{~g} \text { (methionine), } 30 \mathrm{~g} \text { (antibiotic), } \\
20 \mathrm{~g} \text { (BHT). } 3 \text { - Sand. }\end{array}$} \\
\hline
\end{tabular}

One hundred and sixty hens were distributed in a random experimental design with 4 treatments (oil source - soy, canola, fish and poultry by-product) and
5 replicates of 8 birds each. The general management of hens followed the strain recommendations (Manual de criação e manejo, 1996).

\begin{tabular}{|c|c|c|c|c|}
\hline \multirow[t]{2}{*}{ Fatty Acid (\%) } & \multicolumn{4}{|c|}{ Oils source } \\
\hline & Soy & Fish & Canola & $\begin{array}{l}\text { Poultry by- } \\
\text { product }\end{array}$ \\
\hline Total saturated fatty acid & 0.28 & 11.64 & 0.59 & 7.70 \\
\hline Total unsaturated fatty acid & 99.72 & 88.36 & 99.41 & 92.79 \\
\hline Total n3 fatty acid & 23.91 & 21.40 & 66.96 & 39.07 \\
\hline Total n6 fatty acid & 56.46 & 11.10 & 19.20 & 25.46 \\
\hline Total n9 fatty acid & 3.81 & 27.80 & 3.97 & 5.61 \\
\hline Ratio n3:n6 & 0.42 & 1.93 & 3.49 & 1.53 \\
\hline Ratio n3:n9 & 6.27 & 0.77 & 16.87 & 6.97 \\
\hline
\end{tabular}

The experimental period was 84 days divided in three cycles of 28 days each. A total of $3 \mathrm{~mL}$ of blood drawn by cardiac puncture was collected from the same hen at 7:00am, 11:00am and 3:00pm on the last day of each cycle, being two hens per replicate choose at random.

Plasma was obtained by blood centrifugation and total cholesterol, HDL-cholesterol and triacylglicerol were determined using commercial kits (LabTest Diagnosis).

The data were submitted to analysis of variance according to Banzatto \& Kronka (1992) using the software "Sistema de Análise Estatística". The means were compared using the test of Tukey at $5 \%$ probability.

\section{RESULTS AND DISCUSSION}

The means plasma total cholesterol, HDL-cholesterol and triacylglicerol, as well as egg yolk total cholesterol contents obtained at the end of each laying cycle are shown in Table 3. Plasma values were not affected $(p>$ 0.05 ) by dietary treatments, indicating to be a singular characteristic of the laying hens, as pointed out by Chapman (1980). Previous reports had indicated that plasma cholesterol concentration is not related to egg yolk lipid level, although synthesized in the liver and transported by the blood (Sutton et al., 1984; Mendonça Jr., 1996). However, total cholesterol of egg yolk was affected by dietary oil source $(p<0.05)$ with lower values verified when soy oil was added to the ration.

Beyer \& Jensen (1991) reported that the level of plasma cholesterol shows great variation suggesting that this effect could represents the synthesis and excretion of cholesterol through the liver, associated 
Table 3 - Plasma total cholesterol $(\mathrm{mg} / \mathrm{dL})$, HDL-cholesterol $(\mathrm{mg} / \mathrm{dL})$ and triacylglicerol $(\mathrm{mg} / \mathrm{dL})$ of laying hens, and egg yolk total cholesterol $(\mathrm{mg} / 100 \mathrm{~g})$ fed with diets containing different oil sources during the experimental period.

\begin{tabular}{|c|c|c|c|c|}
\hline Oil source & $\begin{array}{l}\text { Total cholesterol } \\
\text { (plasma) }\end{array}$ & $\begin{array}{l}\text { HDL-Cholesterol } \\
\text { (plasma) }\end{array}$ & $\begin{array}{l}\text { Triacylglicerol } \\
\text { (plasma) }\end{array}$ & $\begin{array}{l}\text { Total cholesterol } \\
\text { (egg yolk) }\end{array}$ \\
\hline Soy & 095.67 & 4.13 & 1216.81 & $1291.73 a^{1}$ \\
\hline Fish & 113.00 & 6.07 & 983.47 & $1335.10 \mathrm{a}$ \\
\hline Canola & 126.20 & 4.27 & 1319.08 & $1301.65 a b$ \\
\hline Poultry by-product & 116.40 & 4.07 & 1811.97 & $1322.62 \mathrm{ab}$ \\
\hline$C V(\%)^{2}$ & 77.73 & 102.92 & 75.18 & 2.53 \\
\hline
\end{tabular}

with the feed consumption or the ovulation period of the hen. A possible explanation for not being a clear relation between the blood cholesterol and the yolk cholesterol may lie on the fact that the available blood cholesterol for the growing oocyte rapidly varies in relation to time.

Plasma levels of triacylglicerol and total cholesterol did not differ $(p>0.05)$ during the day, but plasma HDL-cholesterol levels was different $(p<0.05)$ (Table $4)$. The lowest plasma level of HDL-cholesterol was obtained at 11:00 am. According to Chobanian \& Hollander (1962), this difference could be due to the observation that HDL-cholesterol belong to the "fast turnover cholesterol pool"; and yet, it can still be related to the interval between egg production, considering that $80 \%$ of hens lay eggs in the morning.

Table 4 - Daily plasma total cholesterol (mg/dL), HDL-cholesterol $(\mathrm{mg} / \mathrm{dL})$ and triacylglicerol $(\mathrm{mg} / \mathrm{dL})$ changes of laying hens fed different dietary oil source, with samples obtained at the $7 \mathrm{am}$, $11 \mathrm{am}$ and $3 \mathrm{pm}$

\begin{tabular}{|c|c|c|c|}
\hline Hour of collection & $\begin{array}{c}\text { Total } \\
\text { cholesterol }\end{array}$ & $\begin{array}{c}\text { HDL- } \\
\text { Cholesterol }\end{array}$ & Triacylglicerol \\
\hline 07:00 am & 120.90 & $4.90 a^{1}$ & 1498.08 \\
\hline $11: 00 \mathrm{am}$ & 108.50 & $3.70 \mathrm{~b}$ & 1273.93 \\
\hline 03:00 pm & 109.05 & $5.30 \mathrm{a}$ & 1226.49 \\
\hline $\mathrm{CV}(\%)^{2}$ & 139.23 & 24.41 & 45.77 \\
\hline
\end{tabular}

\section{CONCLUSION}

Feeding diets containing different oil sources (soy, fish, canola and poultry by-product oils) at 3\%, has no effect on plasma total cholesterol, HDL-cholesterol and triacylglicerol levels of laying hens plasma, but plasma level of HDL-cholesterol seems to be related with egg formation cycle.

\section{REFERENCES}

Banzatto DA, Kronka SN. Experimentação agrícola. Jaboticabal: FUNEP, Jaboticabal, 1992. 247p.

Bartov I, Bornstein S, Budowski P. Variability of cholesterol concentration in plasma and egg yolk of hens and evaluation of the effects of some dietary oils. Poultry Science 1971; 50:13571364

Beyer RS, Jensen LO. Cholesterol concentration of egg yolk and blood plasma and performance of laying hens as influenced by dietary $\alpha$-ketoisocaproic acid. Poultry Science1992; 71:120-127.

Connor WE, Osborne JW, Marion WL. Incorporation of plasma cholesterol-4- $\mathrm{C}^{14}$ into egg yolk cholesterol. Proceedings of the Society of Experimental Biology and Medicine 1965; 118:710-713.

Chapman D. Animal lipoproteins: chemistry, structure, and comparative aspects. Journal Lipid Research 1980; 21:789-853.

Chobanian AV, Hollander W. Body cholesterol metabolism in man. I. The equilibration of serum and tissue cholesterol. Journal of Clinical Investigation 1962; 41:1732.

Hargis PS. Modifying egg yolk cholesterol in the domestic fowl - a review. World's Poultry Science Journal 1988; 44:17-29.

Holland KG, Grunder AA, Williams CL. Response to five generations of selection for blood cholesterol levels in White Leghorns. Poultry Science 1980; 59:1316-23.

Leaf A, Weber PC. Cardiovascular effects of n-3 fatty acid. New England Journal of Medicine 1988; 318:549-57.

Manual de Criação e Manejo. Lohmann LSL. Uberlândia:Granja Planalto, 1996. 23p.

Mendonça Jr. CX. Colesterol no ovo - possibilidades de sua redução. In: Simpósio Latino-Americano de Nutrição de Suínos e Aves. 1996. Campinas. São Paulo. Brasil. Anais. p.87-118.

Mori AV, Mendonça CX, Santos COF. Effect of dietary lipid lowering drugs upon plasma lipids and egg-yolk cholesterol levels of laying hens. Journal of Agriculture and Food Science 1999; 47:4731-4735. 
Naber EC. The cholesterol problem, the egg and lipid metabolism in laying hen. Poultry Science 1976; 55:14-33.

NRC. National Research Council. Nutrient requirements of domestic animals: nutrient requirement of poultry. Washington: National Academy Science, 1994. 62p.

Romanoff A, Romanoff AJ. The avian egg. (2 $\left.{ }^{\text {nd }}\right)$. New York. 1963. $917 p$.

Sutton CC, Muir WM, Mitchell GE. Cholesterol metabolism in laying hen as influenced by dietary cholesterol, caloric intake and genotype. Poultry Science 1984; 63:972-80.

Washburn KW, Nix DF. A rapid technique for the extraction of yolk cholesterol. Poultry Science 1974; 53:1118-22. 